\title{
Cultural diversity and knowledge in explaining entrepreneurship in European cities
}

\author{
David B. Audretsch • Maksim Belitski • \\ Julia Korosteleva
}

Accepted: 15 April 2019/Published online: 3 June 2019

(C) The Author(s) 2019

\begin{abstract}
This study establishes and empirically explores the relationship between knowledge, cultural diversity and various entrepreneurial outcomes across European cities in 2008-2010. We demonstrate that the mechanism of knowledge spillover entrepreneurship is contextual and contend that cultural diversity and knowledge have differential impact on entrepreneurial outcomes across cities and countries. Cities with high cultural diversity provide more opportunities for entrepreneurship in sectors where technology and knowledge play more important role. While in technology-based sectors, we observe a decline in employment, in cities where cultural diversity is moderately high, this effect is counteracted by an increase in demand for skilful labour that is more concentrated in culturally diverse contexts. Implications for regional and national policy makers and international entrepreneurs are offered.
\end{abstract}

\section{B. Audretsch}

Institute of Development Strategies, SPEA Indiana University,

1315 E. 10th St, Bloomington, IN 47405, USA

e-mail: daudrets@indiana.edu

\section{Belitski}

Henley Business School, University of Reading, Whiteknights, Reading RG6 6UD, UK

e-mail: m.belitski@reading.ac.uk

M. Belitski

ICD - International Business School, 12 rue Alexandre Parodi, Paris 75010, France

J. Korosteleva $(\triangle)$

School of Slavonic and East European Studies, University College London, 16 Taviton Street, London WC1H 0BW, UK

e-mail: J.Korosteleva@ucl.ac.uk
Keywords Cultural diversity · Entrepreneurship · Knowledge spillover · Industry · City

JEL classification $\mathrm{L} 25 \cdot \mathrm{O} 30 \cdot \mathrm{R} 10 \cdot \mathrm{I} 26$

\section{Introduction}

Economists and policy makers have long observed that regional success depends upon entrepreneurial activity (Audretsch 2007; Glaeser et al. 2010) which varies systematically across space (Delgado et al. 2010). As a result, the topic of the determinants of entrepreneurial dynamics across regions and countries has engaged a number of entrepreneurship, regional development and international business scholars. Despite the progress, most studies across countries continue to suffer from the major limitation - an assumption of cultural homogeneity within nations (Tung 2008). Given the growing cultural diversity within and across countries, regional variations can often be as significant as cross-country differences. Despite evidence of the macro-level factors (Agarwal et al. 2007; Delmar et al. 2011; Acs et al. 2014), mechanisms and contextual conditions under which cultural diversity and knowledge transfer support new ideas and productivity (Gomez-Mejia and Palich 1997; Van Wijk et al. 2008; Stahl et al. 2010; Spanjer and van Witteloostuijn 2017), there is still lack of a systemic analysis linking knowledge and diversity to entrepreneurial outcomes especially in the context of cross-city cross-country comparisons (Audretsch et al. 2015a; Dheer 2017). 
Cities have always had a privileged role as centres of culture and economic activity. Bigger, more diverse cities experience greater interactions among individuals from different cultures, where greater cultural diversity generates new entrepreneurial ideas and replaces inefficient entrepreneurial initiatives by productive ones (Cowen 2002). Thus, cities characterized by a high level of knowledge but also cultural diversity may form an ideal ecosystem to explore and commercialize entrepreneurial ideas.

The rationale behind this approach is that culture is an integral structural attribute of any community and is powerful enough to establish boundary conditions on the impact of knowledge spillover entrepreneurship (Rauch et al. 2013; Kreiser et al. 2010; Leung et al. 2005). This mechanism has received limited attention in international business literature (Agarwal et al. 2010; Liu et al. 2010; Rauch et al. 2013).

While there is a general consensus among academic scholars about the importance of high-skilled labour and knowledge-intensive industries for city growth (Glaeser et al. 2004; Audretsch et al. 2015a), there is a longstanding argument on the role of cultural diversity as a conduit of knowledge spillovers and creativity (Legrain 2006; Putnam 2007; Liu et al. 2010; Nathan 2012) earlier introduces within the knowledge spillovers theory of entrepreneurship (Audretsch et al. 2006). The incremental benefit it brings to business formation, job creation and start-up survival remains an open question (Qian 2013). The overall economic growth benefits across cities may vary depending on a combination of knowledge embedded in the industry, diversity of skills and experiences (Spanjer and van Witteloostuijn 2017) and cultural diversity embodied in city communities (Nathan 2012; Audretsch et al. 2010). Firms in knowledge-intensive industries that are located in culturally diverse areas and able to employ people with diverse backgrounds may grow faster, but they also tend to develop a great deal of complexity and uncertainty as a result of cultural diversity (Robertson and Swan 2003).

The mechanism via which geographically localized knowledge and cultural diversity impacts entrepreneurial dynamics in an international setting has become an important question in strategic international entrepreneurship (Hitt et al. 2002; Agarwal et al. 2007, 2010) and regional development literature within (Audretsch and Lehmann 2005; Marino et al. 2012; Acs et al. 2013; Qian 2013). Respectfully, this study aims to establish and empirically explore the complexities of the relationship between knowledge intensity, cultural diversity and entrepreneurial outcomes, rendering some policy-making implications for their role in explaining entrepreneurial dynamics across European cities and countries.

We employ a multilevel analysis spanning industries in the context of European cities during 20082010 , and simultaneously evaluate the effect of cultural diversity, embeddedness of firms in knowledge-intensive environment, and the interplay between them on three entrepreneurial outcomes, namely, entrepreneurial entry, survival and highgrowth employment start-up rates.

Building on the prior research, this study makes the following contributions to strategic entrepreneurship, regional development and international business literature.

First, while there is a growing body of empirical work on the determinants of entrepreneurial dynamics across cities, the majority of them focus on specific country case studies and macro level antecedents of entrepreneurship (Boschma and Fritsch 2009; Acs et al. 2014), whereas the research on cross-country cross-city comparisons is still fairly limited (Tung 2008; Bosma et al. 2012; Amoros, Bosma and Levie 2013; Bosma and Sternberg 2014; Korosteleva and Belitski 2017). Our study makes a methodological contribution and bridges this gap by employing the unique dataset using Eurostat industry-city statistics data on high-growth businesses, survival and net entry rates, merged with Eurostat socioeconomic city-country level data to enable cross-country comparative analysis of entrepreneurship dynamics from a multi-level industrycity-country perspective.

In addition, we construct a new measure of cultural diversity which includes infrastructure acumen as city amenities (i.e. localized knowledge-exchange spaces attractive to high-skilled workers) and external knowledge, measured as temporary or permanent exposure of a city to overseas culture and ideas via varieties of tourism and residence mechanisms. Although fairly straightforward, we are unaware of any research involving cultural diversity, knowledge intensity and entrepreneurial outcomes which employs this methodological framework.

Second, the prior research demonstrated that start-up rates and post-entry performance are largely linked to the underlying technological conditions in an industry (Geroski 1995; Audretsch 1995), whereas the incremental impact of cultural framework (Audretsch et al. 2010), in particular, across different entrepreneurial outcomes and countries has been neglected (Autio et al. 2013). We establish and empirically explore the idiosyncratic 
impact of cultural diversity and knowledge intensity on different entrepreneurial outcomes within industry-citycountry context.

To explore our research questions empirically, we employ the seemingly unrelated regression equations (SURE) model combined with both the OLS and Tobit approach to simultaneously study all three entrepreneurial outcomes of interest, namely new firm formation, survival and high-employment growth start-ups within industry-city level context. This enables us to overcome the problem of potential endogeneity between the outcome-dependent variables.

This study is organised as follows. Section 2 provides the theoretical background on cultural diversity, knowledge and their relationship with entrepreneurial outcomes. Section 3 discusses data, variable definition and the methodology. Section 4 presents empirical results, while Section 5 concludes.

\section{Theoretical conceptualization and hypotheses}

\subsection{The role of knowledge and diversity in explaining} entrepreneurship dynamics

It is argued that bigger and culturally diverse cities attract individuals with greater human capital and capabilities and this affects regional economic development (Florida 2002; Audretsch et al. 2015a). The argumentation behind this is largely rooted in the Information, Consumption and Reinvention approaches to city development (Glaeser et al. 2004).

In particular, the Information City approach view suggests that cites are places where there are a constant flow and exchange of ideas, so high-growth cities are likely to exhibit higher presence of skilled and highly qualified individuals, facilitating entrepreneurial entry and new venture growth. The ability of cities as agglomerated locations to foster new ideas is one potential reason why they become centres of entrepreneurship (Chinitz 1961; Audretsch and Lehmann 2005). Exchange of ideas both within and across industries in cities may generate horizontal and vertical spillovers and facilitates inter-organizational knowledge transfer of new ideas (Van Wijk et al. 2008), which can further create and sustain businesses. The Jacobian externalities attempt to determine that diversified knowledge and industries are more conducive to knowledge generation and exchange (Beaudry and Schiffauerova 2009).
The Consumer view of a city advocates for skilled employees with high absorptive capacity are attracted by city cultural amenities which further facilitates knowledge exchange (Glaeser et al. 2001, 2004; Florida 2002). The diversity of people and cultures attracted by cultural amenities may be expected to offer more opportunities for crossfertilization of ideas within and outside those spaces, contributing to the intensity (and to the novelty) of regional knowledge generation. In empirical analysis, this may be entirely captured by the knowledgegeneration measures and absorbed into the existing KSTE framework.

There are several types of important cultural amenities in cities. First, are restaurants, theatres and cinemas which add to lifestyle and life quality. Second, aesthetic and physical settings include architectural and a landscape beauty in a city which attract both high-skilled workers and tourists. More aesthetically attractive places will bring tourism and create spots for meetings and communication, facilitating information and ideas exchange. Third, public services and provision of knowledge, transport links and infrastructure is an important amenity embedded into local context where business operates (Autio et al. 2014; Audretsch et al. 2015b).

Finally, the Reinvention City view argues that cities adapting to emerging technologies faster will survive (Glaeser 2005). For such cities, a diversity of industries and people is likely to facilitate interactions of people with diverse backgrounds working in different industries or possessing different cultural heritage which makes them more agile to changes. Famous study by Spanjer and van Witteloostuijn (2017) supports a more complex, non-linear effect of diversity of skills and knowledge on entrepreneurial outcomes, where experience diversity is measured as the number of skills linked to an entrepreneur's jobs and the number of knowledge fields associated with the entrepreneur's jobs is associated. Heterogeneous knowledge acquired by entrepreneurs and interactions with people with different job experiences and background may promote unorthodox perception of the new knowledge generated by technological change and increase chances of new market application of knowledge and new business formation in a spirit of KSTE.

Overall, all three views are important in understanding the role that knowledge and various forms of cultural diversity as a source for new business ideas play in new business formation and urban economic development. 
These three perspectives should be aligned to work as a single mechanism and enable strategic management of the knowledge spillover entrepreneurship. The KSTE argues that the ability of knowledge-intensive environments to foster new ideas can generate entrepreneurial opportunities and their commercialization, leading to ultimate urban success (Audretsch and Lehmann 2005; Audretsch et al. 2006; Agarwal et al. 2010; Acs et al. 2013).

More specifically, entrepreneurial opportunities that emerge from a society's investment in human capital, research and development (Saxenian 1994) generate new knowledge that further 'spills over' to a third party when it flows between economic agents, with a third party not incurring the costs of knowledge production (Audretsch and Feldman 1996). Although this may impose certain appropriability risks (Laursen and Salter 2014), spillover of knowledge is desirable as it reduces the public and private cost of innovation which enables new business as a way to commercialize ideas (Audretsch et al. 2006) and increases return to investment in knowledge.

Agarwal et al. $(2007,2010)$ develop a model of 'creative construction' which shows how knowledge spillovers combined with an entrepreneurial action enable knowledge appropriation, which leads to the creation of dynamic ventures. Entrepreneurs play the central role as conduits of knowledge spillovers. Therefore, a knowledge-intensive environment, conducive to opportunity discovery, may influence venture creation and positively influence start-ups' survival and growth.

However, it is not only a knowledge-intensive environment rich in research and development that would serve as a potential source for new ideas and knowledge spillover entrepreneurship. It is also cultural diversity embodied in creative individuals which serves as an important source for entrepreneurial opportunities, driving the entry of new start-ups (Leung et al. 2005; Kreiser et al. 2010; Marino et al. 2012; Audretsch and Belitski 2013).

Qian (2013) following Florida's (2002) The Rise of the Creative Class advocates for cultural diversity as a form of urban amenity and an important factor for attracting skilled labour (Florida 2002; Florida et al. 2008). City tolerance to other cultures contributes to talent attraction from various countries, including the talent settling in a city and a talent which visits a city for business and leisure. More specifically, Melting Pot Index, measured as the relative percentage of foreign- born people in a region, was sometimes used interchangeably as a proxy for cultural diversity and tolerance in cities (Qian 2013).

Diversity of ideas and backgrounds and ability to exchange them within urban spaces attract high-skilled workers and, most importantly, retain talent (Florida 2002). Cultural diversity is crucial in this context because, in addition to experience diversity advocated by Spanjer and van Witteloostuijn (2017), tolerance to new ideas is important for new market opportunities. This may include people coming from different countries of birth, religious beliefs, customs and traditions, sexual orientations, and languages. In particular, ethnically diverse cities, featuring diversities in cultures and social norms, will attract people who value diverse experiences (Olfert and Partridge 2011). A familiar feature of this growing diversity is that it is largely urbanized (Nathan 2012). European cities have the highest numbers of migrants and minority groups in the world (Landry and Wood 2008), but also have high mobility and knowledge flow. Cultural diversity becomes part of the mechanism in attracting high human capital. The positive association between cultural diversity and highly skilled labour has been found in a number of studies (Boschma and Fritsch 2009; Sobel et al. 2010). It creates an environment of tolerance to new ideas. Altogether, it contributes to the exchange of new nonconventional ideas, creating new markets with people feeling nonthreatened to exchanging and expressing ideas and pushing and pulling them forward in creating so-called 'culturally diverse areas' within existing urban spaces.

Cultural diversity also creates an environment conducive to networking and the exchange of ideas (Leyden et al. 2014). For example, residents coming from different backgrounds and cultural experience (Lee 2011), including residents from non-EU countries permanently residing in European cities and tourists visiting cities, all have different perspectives of thinking and ability to see opportunities, which makes designing new products, services and processes, or modifying the existent ones more likely (Kreiser et al. 2010; Qian 2013). To the extent that cultural diversity contributes to the development of the knowledge-intensive context, and with variety of ideas, conducive to opportunity discovery, it is likely for cultural diversity to influence entrepreneurial entry. Knowledge spillover theory of entrepreneurship prospective (KSTE) provides support for the variety of ideas and knowledge to be important source of entrepreneurial opportunities at local and country levels 
(Audretsch and Lehmann 2005; Audretsch et al. 2006; Rauch et al. 2013; Acs et al. 2013).

Empirical evidence suggests that new business formation and survival in high-tech sectors are systematically greater in regions rich in knowledge (Geroski 1995; Audretsch and Feldman 1996; Audretsch et al. 2006) and in regions where amenities facilitate cultural exchange (Glaeser et al. 2001; Nathan 2012). Audretsch and Dohse (2007) have also demonstrated that firms which were located in regions with diverse knowledge exhibited higher rates of growth and survival than if the location is in a region with a paucity of knowledge endowment. In addition, entrepreneurs themselves are part of a region's talent pool and are also attracted to tolerant, diverse environments. Diversity in education, competencies, experiences and skills result in divergence of perceptions and aspirations, as well as the ability to implement ideas independently through employment or entrepreneurship. Localized cultural diversities (Glaeser et al. 2001; Falck et al. 2011; Rauch et al. 2013; Leyden et al. 2014) serve as a strategic tool for market entry and survival. We therefore hypothesise:

H1a: Knowledge-intensive industries and cultural diversity are likely to have positive impact on new business formation.

H1b: Knowledge-intensive industries and cultural diversity are likely to have positive impact on start-up survival rates.

Knowledge intensity embedded in industry and cultural diversity embodied in city communities per se are unlikely to facilitate start-up employment growth. First, prior research discovered that cultural framework indirectly influence growth by shaping the legal framework, traditions, ideas and forms of interaction (Chambers and Hamer 2012; Rauch et al. 2013). Whereas cultural diversity is likely to play an important role in market entry and survival, it is unlikely to change significantly over a short period of time, which limits inflow of new ideas and knowledge and may not be sufficient to generate significant changes in employment growth (Qian and Acs 2013; Audretsch and Belitski 2013).

Second, technological knowledge is important in recognising entrepreneurial opportunities and sustaining competitive advantage (Siegel and Renko 2012; Qian and Acs 2013), however, its effect on job creation can be ambiguous. Investment in new technology may increase the individual demand for labour, if the technical elasticity of substitution is less than one, otherwise introduction of new technology may lead to job destruction.
Digitalization in knowledge-intensive sectors may limit the use of human resources with businesses finding themselves in the need to leverage the traditional business models in particular through applying different type of resources and technology (LEAD 2014; Li et al. 2016). The opportunity offered by emerging technologies could be critical to growth but may have negative implications for employment. ICT enables businesses to reduce the number of intermediaries, search, maintenance, transaction and labour costs, along with the benefits of network externalization (Martin and Wright 2005).

In knowledge-based industries such as education, ICT, creative sectors and finance, ICT-led platforms and digital capabilities are in place to facilitate recognition, transformation and exploitation of new technologies (Teece et al. 1997; Robertson and Swan 2003; LEAD 2014) where we expect high start-up and survival rates, although lower labour-intensity, hence lower employment growth rates. Respectively, we hypothesise:

H1c Knowledge intensity is likely to have an adverse effect on high-employment-growth entrepreneurship, whereas city cultural diversity is unlikely to render any impact on high-employment growth entrepreneurship.

\subsection{The interplay between cultural diversity and knowledge intensity}

Diversity in cities that people bring with them triggers complementarities in knowledge and skills for firms and leads to more business opportunities which allow to explore entrepreneurial opportunities for start-ups and to further sustain their market positions. Experimental studies highlighted that diversity of economic agents accelerates the knowledge creation but these dynamics appear particularly important in knowledge-intensive rather than labour-intensive industries (Fujita and Weber 2003; Kenney et al. 2013) where creativity, science and technology play an important role. Gambardella and Giarratana (2010) in their well-cited study highlighted an important consequence of the process of 'creative construction': localized knowledge and skills increase the productivity of skilled employees and knowledge-intensive firms disproportionately more compared to less-skilled employees and labourintensive firms. Gambardella and Giarratana (2010) discuss the implications of skilled and unskilled labour for regional level dynamics when knowledge spillovers are 
localized. The process of 'creative construction' is rooted into new knowledge which can be generated and disseminated via different conduits, including knowledge embedded in industries and cultural diversity embodied into city communities. It is further facilitated by the exchange and cross-fertilization of knowledge and skills, experiences, leading to the discovery and creation of new market opportunities, start-ups and allowing for knowledge accumulation to enable new venture survival and growth.

We contend that cultural diversity is an integral structural attribute of any community and is powerful to create boundary conditions and change entrepreneurial outcomes through knowledge spillovers of entrepreneurship (Kreiser et al. 2010; Rauch et al. 2013; Dheer 2017) with the effect being particularly strong in knowledge-intensive contexts (Florida et al. 2008; Audretsch et al. 2006, 2010; Delmar et al. 2011; Qian and Acs 2013). Ahlstrom and Bruton (2002) studied high-technology entrepreneurial firms in China, demonstrating how cultural differences led managers to employ tactics and knowledge different from the Western companies to leverage the contextual differences to develop competitive advantage and survive.

Drawing on these insights, we argue that the relationship between cultural diversity and various entrepreneurial outcomes is not only direct but also indirect. The rationale is that cultural diversity acts as both a direct and indirect mechanism to help entrepreneurs identify new opportunities and assemble the resources they need to exploit an opportunity in the market place. Heterogeneity of knowledge and cultural diversity leads to heterogeneous entrepreneurial outcomes. Cultural diversity affects community's ability to value, assimilate, and apply new knowledge including both market and technological knowledge (Qian and Acs 2013), and it is not only extremely relevant to entrepreneurial entry but also start-up survival and early stage high-growth (Tidd and Bessant 2014).

Diversity in cultural experiences and skills makes economic agents value ideas differently and hence recognise different opportunities to start a new business (Geroski 1995; Agarwal et al. 2007; Autio et al. 2014). The greater cultural diversity of a city, the more unique an evaluation of any new knowledge within a given sector and city will be, and the higher the likelihood of creating multi-product markets and extending product life-cycles to sustain firm survival rates and ensure their ultimate growth will be.
Therefore, we hypothesise that cultural diversity will moderate the knowledge spillover of entrepreneurship and act as a conduit of opportunity recognition and market creation mechanism.

H2a: Cultural diversity positively moderates net entry in knowledge-intensive industries.

$\mathrm{H} 2 \mathrm{~b}$ : Cultural diversity positively moderates survival in knowledge-intensive industries.

$\mathrm{H} 2 \mathrm{c}$ : Cultural diversity positively moderates high growth-employment entrepreneurship in knowledgeintensive industries.

\section{Data, variable definition and methodology}

\subsection{Data description}

Our main source of data for our dependent variables is Eurostat Regional statistics for 2008-2010, merged with European Urban Audit data, containing cultural diversity variables related to our key set of hypotheses and other city-level controls. Our dependent variables are cross-industry data, spanning 11 industries by statistical classification of economic activities in the European Community known as NACE, cross-city and cross-EU countries available for the years of 2008 and 2010 as two repeat cross-sections. Eurostat Urban Audit data that provide urban socioeconomic and demographic statistics are collected in waves. ${ }^{1}$ We merge Eurostat (2012) Urban Audit statistics for the reference years of 2006 and 2009 to the years of 2008 and 2010 of Eurostat (2012) city-industry business statistics respectively.

Our final dataset yields 1144 observations covering 11 industries in 67 cities across 8 European countries (Czech Republic, Denmark, Spain, Hungary, Italy, Poland, Romania and Slovakia). The Appendix provides information on the average value of employment growth, survival rate and new firm start-up rates by city. $^{2}$ City is described here as the Functional Urban Area (formerly known as larger urban zone LUZ), which consists of a core city and its commuting zone. A core city is a local administrative unit (LAU) where the majority of the population lives in an urban centre of at least 50,000 inhabitants (Eurostat 2015). The 'core

\footnotetext{
${ }^{1}$ Currently, five waves of Eurostat Urban Audit Statistics survey data (Eurostat 2012; Eurostat 2015) are available reflecting the following reference years for data collection: 1996, 2001, 2004, 2006, 2009.

${ }^{2}$ German, French and the UK cities were not included as the data on industries is available at the regional level only in Eurostat.
} 
city' definition used in the Urban Audit corresponds to the 'administrative city' with political responsibility (usually the municipality or equivalent) in all cases, with exception of Brussels and Cyprus.

The focus on an industry city is explained by three main reasons highlighted in a number of important studies linking regions to entrepreneurship (Audrestch and Lehmann 2005; Bosma and Sternberg 2014). First, most entrepreneurial action takes place in cities (Bosma and Sternberg 2014; Szerb et al. 2013; Audretsch et al. 2006). Second, in Europe, there exist significant differences in sectoral structure and socioeconomic development across clusters of cities, which reflect the importance of regional and more specific city focus (Saxenian 1994). Thirdly, local cultural context is seen as a localized 'container', enabling diversity and localization of existing and incoming culture (Nathan 2012) and knowledge spillovers (Audretsch and Feldman 1996; Gambardella and Giarratana 2010).

\subsection{Dependent variables}

Our three dependent variables measure entrepreneurial dynamics at an industry-city level. The choice of dependent variables is triggered by exhaustive literature linking local context characteristics (Acs et al. 2013, 2014) to entrepreneurial activity often described as entrepreneurial flow (firm entry and exit; proportion of high-growth enterprises) and stock (survival) (Shane and Venkataraman 2000; Audretsch 2007; Zahra and Wright 2011; Coad et al. 2013).

Respectively, we focus on the following three entrepreneurship outcome variables:

(a) A number of net business entry by industry city at time $t$ normalised by the total number of enterprises in this industry city at time $t$ (Audretsch et al. 2006; Glaeser et al. 2014).

(b) A number of start-ups born in t-3 (2005-2007) and survived to $t$ by industry city (2008-2010) normalised by the total number of enterprises in this industry city at time $t$ (Audretsch and Feldman 1996; Agarwal and Audretsch 2001; Saridakis et al. 2008; Coad et al. 2013).

(c) A number of high employment growth start-ups by industry city $(10 \%$ or more employment growth over the last 3 years) at time $t$ normalised by the total number of enterprises in this industry city at time $t$ (see descriptive statistics in Table 1).

Table 1 Variables description and summary statistics

\begin{tabular}{|c|c|c|c|c|c|c|}
\hline Variable & Obs. & Description & Mean & St.dev & Min & Max \\
\hline 1. Net entry ratio & 671 & $\begin{array}{l}\text { Number of start-up net entry in } t \\
\text { to all businesses in } t\end{array}$ & 0.016 & 0.041 & -0.14 & 0.15 \\
\hline 2. Survival ratio & 1144 & $\begin{array}{l}\text { Number enterprises born in } \mathrm{t}-3 \text { survived to } t \text {, to } \\
\text { all businesses in } t\end{array}$ & 0.06 & 0.02 & 0.02 & 0.17 \\
\hline 3. High-growth ratio & 798 & $\begin{array}{l}\text { Number of start-ups with high-employment-growth } \\
(10 \% \text { and more }) \text { in } t \text { to all enterprises in } t\end{array}$ & 0.005 & 0.004 & 0.00 & 0.03 \\
\hline 4. Population density & 1144 & Population density, in logs & 7.41 & 0.96 & 4.55 & 9.66 \\
\hline 5. GDPpc in ppp & 1144 & GDP per capita in Purchasing Power Standard in logs & 9.63 & 0.51 & 8.19 & 10.47 \\
\hline 6. Cultural diversity & 1144 & $\begin{array}{l}\text { Standardized item - cultural diversity calculated with } \\
\text { Cronbach alpha using items } 8-13 \text { in this table }\end{array}$ & -0.03 & 0.71 & -0.74 & 4.93 \\
\hline $\begin{array}{l}\text { 7. High-tech and knowledge- } \\
\text { intensive activities }\end{array}$ & 1144 & $\begin{array}{l}\text { High tech sector dummy = } 1 \text { if includes ICT, creative } \\
\text { services, education and health, finance and insurance } \\
\text { services; science and tech, and zero otherwise }\end{array}$ & 0.45 & 0.50 & 0.00 & 1.00 \\
\hline 8. Cinema & 1023 & Annual cinema attendance per resident & 3.47 & 2.08 & 0.10 & 11.70 \\
\hline 9. Theatre & 715 & The number of theatres & 10.63 & 11.45 & 0.00 & 56.00 \\
\hline 10. Museum & 1045 & Number of museums & 16.80 & 18.88 & 1 & 100.00 \\
\hline 11. Tourists & 1144 & Number tourist overnight stays per resident & 3.19 & 3.73 & 0.40 & 26.10 \\
\hline 12. Non-nationals & 1100 & Non-EU nationals as $\%$ total population & 2.71 & 3.12 & 0.04 & 12.22 \\
\hline
\end{tabular}

Items $8-12$ are taken at a city level and used in the calculation of a cultural diversity standardised index. Item 1 is at the industry-city level. Sorted as in the model

Source: Eurostat (2012) 


\subsection{Explanatory and control variables}

So far, a way of measuring cultural diversity has been limited to Theil index (Brülhart and Trager 2005) and other measures such as the Boho Index, the Gay Index, or the Melting Pot index which are all reflections of cultural diversity when combined into one of Florida's 3Ts (Florida 2002). Other recent indicators include a measure of cultural tolerance and diversity in economic geography (Nathan 2012; Qian 2013). Ethnolinguistic fractionalization approach and the cultural diversity index for the US regions, measures the probability that two randomly chosen individuals belong to two ethnic groups in a region (Sobel et al. 2010), and notwithstanding the difference in the size of a region is unable to capture a spatial context of cultural diversity. The Theil index and Florida's cultural diversity measures do not capture the importance of infrastructure and amenities for entrepreneurship dynamics (Autio et al. 2014; Szerb et al. 2013; Audretsch et al. 2015b).

Cultural diversity calls for diversity among talent in cultures, countries of birth, religious beliefs, and sexual orientations, but this term becomes more complex while applied in a spatial context, like area, city or region (Lee 2011). Ethnically diverse cities feature diversities in cultures that may signal as 'places to go' or 'no-go' for workers as consumers of local amenities reflecting on the Consumer view of a city (Glaeser et al. 2004; Boschma and Fritsch 2009). Highly skilled people from various cultural and work backgrounds are attracted by diversity and new experiences (Florida 2002; Glaeser et al. 2001; Olfert and Partridge 2011).

Cultural diversity is reflected through greater embeddedness of people's competences, skills and backgrounds within a specific local context and faceto-face interactions (Falck et al. 2011; Szerb et al. 2013) representing the Information view of a city (Glaeser et al. 2004). Cultural diversity is closely linked to the ways opportunities are recognized and transformed into tangible products enabling market entry. A comprehensive study on diversity and differences in interpretations, heuristics and predictive models were found to be able to improve problem-solving and experimentation in businesses reinventing the cultural and business spaces (Shapiro 2003; Page 2007) embedded in a nature of entrepreneurship and innovation in cities. This complements cultural diversity as enabler of Reinvention view of city development, innovation and emerging technologies (Shapiro 2003; LEAD 2014).
Following the earlier studies (Brülhart and Träger 2005; Sobel et al. 2010; Audretsch et al. 2010; Nathan 2012; Qian 2013; Dheer 2017), broadly rooted in the Information, Consumption and Reinvention approaches to city development (Glaeser et al. 2004) discussed above, we operationalise cultural diversity as a complex systemic scale variable based on a number of relevant variables and construct an index which includes diversity embedded in foreign temporary visitors and residents (i.e. a number of tourists (business and leisure) overnight stays per resident, and proportion of non-EU nationals as percentage of total population ${ }^{3}$ ) creating a social network effects and ideation, blended with availability and usage of local cultural amenities and infrastructure (i.e. number of cinemas, theatres, museums) (Audretsch et al. 2015b). Although cultural amenities may not become forums for entrepreneurial knowledge sharing, they will serve as diversified cultural areas to attract diverse cultures in cities as per Glaeser et al. (2004) consumption view. Of course, an increase in number of cinemas, theatres and museums may be associated with a particular public investment strategy in culture or historical philanthropy and not with an influx of creative class (Florida 2002). However, it does not change the mechanism which attracts diverse cultural groups into a city which further enables the KSTE mechanism. Urban amenities enhance and create an ecosystem of entrepreneurship and innovation (Acs et al. 2014; Autio et al. 2014; Audretsch and Belitski 2016) associated with more efficient problem solving and opportunity search.

The index is constructed based on the standardised values of these aggregates with alpha reliability coefficient being equal to 0.81 . We validate the index using the factor analysis, using the principal component factor method to analyse the correlation matrix, and using the varimax rotation option. The eigenvalue indicates that all our variables load into a single factor which confirms the importance to consider all these elements of cultural diversity (amenities and external knowledge) within a single construct (see Tables 2 and 3).

Our second variable of interest is embeddedness in knowledge-intensive environment. Eurostat regional

\footnotetext{
${ }^{3}$ This study views European Union as a single institutional system, associating the presence of non-EU members with higher cultural and cognitive distances than European culture. Non-EU citizens are also required to register with police, while EU citizens are not obliged to do so, which creates underestimation of such indicator in a cultural diversity and may be skewed towards tourist cities.
} 
Table 2 Factor analysis using principal component factor method

\begin{tabular}{llll}
\hline Factor & Eigenvalue & Difference & Proportion \\
\hline Factor 1 & 3.02 & 2.33 & 0.60 \\
Factor 2 & 0.69 & 0.18 & 0.14 \\
Factor 3 & 0.5 & 0.05 & 0.10 \\
Factor 4 & 0.45 & 0.12 & 0.09 \\
Factor 5 & 0.32 &. & 0.07 \\
No of observations & 1232 & & \\
LR test & Chi-squared (10) st. $=2286$ & \\
& $p$ value $=0.0000$ & \\
\hline
\end{tabular}

Source: authors' calculations based on Eurostat (2012)

business demographic statistics used for obtaining our entrepreneurial outcome variables span across 11 aggregated industries (sectors), using NACE Rev. 2 classification. These include such sectors as industry (mining and quarrying; manufacturing; electricity, gas, steam and air conditioning supply; water supply and waste management activities); construction; whole and retail trade; hospitality (accommodation and food service activities); Information and Communication (ICT); financial and insurance activities; professional, scientific and technical activities; public services (education; health and social work activities); creative services (arts; entertainment and recreation); and other activities. Following Eurostat (2014) classification, we further distinguish between knowledge-intensive services and technologyintensive industries. Respectively, we define ICT, creative services; financial and insurance activities; professional, scientific and technical activities; and public sector services as knowledge-intensive services, whereas other services such as construction, hospitality, and retail and wholesale trade as less knowledge-intensive services.

It is less straightforward to classify industry as lowor high-tech intensive, given that in Eurostat regional

Table 3 Rotated factor loadings and unique variances

\begin{tabular}{lll}
\hline Variable & Factor 1 & Uniqueness \\
\hline Cinema & 0.83 & 0.31 \\
Theatre & 0.79 & 0.37 \\
Museum & 0.65 & 0.58 \\
Tourists & 0.79 & 0.38 \\
Non-nationals & 0.81 & 0.34
\end{tabular}

Source: authors' calculations based on Eurostat (2012) business demographic statistics, this category is aggregated to comprise manufacturing; mining and quarrying; electricity and gas; and water supply, spanning B-E NACE Rev. 2 categories. Within the B-E NACE classification, there is a mixture of both low-technology and medium-low technology industries (e.g. recycling, waste, mineral products, basic metal products; various low and medium-technology manufacturing industries), and industries classified as high-tech (manufacture of basic pharmaceutical products and pharmaceutical preparations; computer, electronic and optical products), medium and medium high-tech industries (e.g. electrical machinery and apparatus, chemical transformation of materials, substances, or components into new products; manufacture of machinery and equipment). In the context of our sample, dominated by cities from Central and Eastern and Southern European countries, given the predominance of low-tech and labour-intensive manufacturing industries following the B-E NACE classification, the 'industry' category is likely to represent low-technology intensive industry. Therefore, we further perform some robustness checks by testing the sensitivity of our results to dropping the 'industry' category from the estimation.

Our knowledge-intensive variable is binary with ' 1 ' denoting high-tech industries and knowledge-intensive services and zero otherwise. While our knowledgeintensive variable does not directly measure the amount of knowledge and technology used, it clearly reflects the degree of exploitation of technology and new knowledge in the industry, given that classification of industries between low, medium and high-tech is based on firms' $R \& D$ intensity within the respective industry (OECD 2011).

As far as city-level control variables are concerned, we use the density of population in a city which is found to have a positive impact on start-ups (Chinitz 1961; Stearns et al. 1995; Boschma and Fritsch 2009; Falck et al. 2011). The density measure (population density) is defined here as inhabitants per square kilometre in the cities. Population density is included to capture the impact of agglomeration economies not directly related to knowledge.

We also include GDP per capita at purchasing power parity in a city as a proxy for the level of city economic development known as resource endowment in regional economics literature (Stearns et al. 1995; Bosma et al. 2012; Szerb et al. 2013). We also control for city and industry fixed effects to account for unobserved 
heterogeneity both at an industry and city levels. Finally, we also control for time fixed effects to capture the changes in regulation and the external environment over time. The correlation matrix of the variables is reported in Table 4.

\subsection{Methodology}

To answer our research questions, our regression analysis departs from a model that includes a number of important facets of start-up net entry, survival ratio and high-employment growth.

We model all three entrepreneurial outcomes variables simultaneously given some potential interdependence between the three equations. A standard way of modelling jointly determined indicators is a system of equations - SURE - seemingly unrelated regression equations, where all three equations are linked only by their errors (Zellner 1962).

By estimating a system of equations, we accomplish two objectives. First, address potential endogeneity between entrepreneurial outcome variables allowing for their joint estimation. Second, we improve the efficiency of the estimate because the residuals are interdependent given the potential endogeneity bias. We employ the seemingly unrelated regression equations model combined with both the OLS and Tobit approach for studying all three entrepreneurial outcomes of interest. While all our dependent variables are continuous, the ratio of highgrowth employment start-ups is censored with a substantial number of observations being equal to zero denoting the rate of start-ups that do not substantially contribute to creating employment. The average rate of start-ups with high-growth employment in our sample is $0.5 \%$, where

Table 4 Correlation table

\begin{tabular}{|c|c|c|c|c|c|c|}
\hline Variables & 1 & 2 & 3 & 4 & 5 & 6 \\
\hline $\begin{array}{l}\text { 1. Net entry } \\
\text { ratio }\end{array}$ & 1.00 & & & & & \\
\hline 2. Survival ratio & $0.23 *$ & 1.00 & & & & \\
\hline $\begin{array}{l}\text { 3. high growth } \\
\text { ratio }\end{array}$ & -0.01 & -0.03 & 1.00 & & & \\
\hline $\begin{array}{l}\text { 4. Population } \\
\text { density }\end{array}$ & $0.18^{*}$ & $0.11 *$ & $0.13^{*}$ & 1.00 & & \\
\hline 5. GDP in PPP & $-0.33^{*}$ & $-0.43^{*}$ & $-0.10^{*}$ & $0.17 *$ & 1.00 & \\
\hline $\begin{array}{l}\text { 6. Cultural } \\
\text { diversity }\end{array}$ & $-0.23^{*}$ & $-0.21 *$ & 0.03 & $0.16^{*}$ & $0.47^{*}$ & 1.00 \\
\hline
\end{tabular}

*Significant at 5\% significance level. Source: Eurostat (2012)
$20 \%$ of the distribution has $0 \%$ of start-ups with highgrowth employment. Therefore, while two other dependent variables are estimated using OLS within the SURE framework, the ratio of start-ups with high-growth employment is estimated using a censored Tobit model, previously employed empirically to address the problem of censored data (Laursen and Salter 2006).

We employ the STATA cmp module which allows estimating SURE with the simulated likelihood method such as the Geweke, Hajivassiliou and Keane (GHK) algorithm (for a discussion, see Roodman 2009).

The SURE regression model with industry and city, and time fixed effects represents a system of equations in the following form:

$\left\{\begin{array}{l}E_{(i, j, t, c)}=\beta_{0}+\sum_{j=1}^{n} \beta_{11} x_{j, t, c}+\sum_{j=1}^{n} \beta_{12} z_{j, t, c}+\rho_{1 i}+\rho_{1 j}+\lambda_{1 t}+u_{1(i, j, t, c)} \\ S_{(i, j, t, c)}=\beta_{0}+\sum_{j=1}^{n} \beta_{21} x_{j, t, c}+\sum_{j=1}^{n} \beta_{22} z_{j, t, c}+\rho_{2 i}+\rho_{2 j}+\lambda_{2 t}+u_{2(i, j, t, c)} \\ Y_{(i, j, t, c)}=\beta_{0}+\sum_{j=1}^{n} \beta_{31} x_{j, t, c}+\sum_{j=1}^{n} \beta_{32} z_{j, t, c}+\rho_{3 i}+\rho_{3 j}+\lambda_{2 t}+u_{3(i, j, t, c)}\end{array}\right.$

where $Y_{i, j, t, c}$ is a number of start-ups which demonstrated high-growth employment in industry $i$ in city $j$ at time $t$ in country $c$ as a proportion of all enterprises in industry $i$ in city $j$ at time $t$. We deal with two waves of data for each dependent and independent variable. For example, $Y_{i, j, t, c}$ illustrates high-employment growth of a start-up in 2008 established in 2005. $S_{i, j, t, c}$ is the number of start-ups in industry $i$ in city $j$ and country $c$ born in $t-3$ and survived to period $t$ normalised by total number of enterprises at time $t$ in industry $i$ in city $j . E_{i, j}$, $t, c$ is the number of net entry of start-ups (number of births minus number of deaths) in industry $i$ in city $j$ at time $t$ in country $c$ normalised by total number of enterprises at time $t$ in industry $i$ in city $j . x_{j, t, c}$ is a vector of our variables of interest: knowledge-intensive industry, a measure of cultural diversity and their interaction for a city $j$, country $c$ and period $t . z_{j, t, c}$ is a vector of control variables for a city $i$, period $t$ and country $i$. Moreover, we include three additional vectors of fixed city effect $\rho_{\mathrm{j}}$, controlling for other characteristics of cities which remain unobserved (e.g. health, digital and other physical and soft infrastructure of cities); $\rho_{\mathrm{i}}$ is the industry fixed effects at an industry $i$ over time $t$ (e.g. dependence on finance, industry life-cycle and city sector specialization); $\lambda_{t}$ is a vector of time-fixed (entity invariant effects) over each time period $t$ across all industry $i$, city $j$ and country $c$. The error term is denoted by $u_{i, j, t, c}$ for an industry $i$, city $j$, country $c$, at time $t$. The equations are related to each other having errors that jointly and normally distributed and therefore are inter-dependent. 
We also undertake some robustness checks excluding from our sample the 'industry' category that bundles together manufacturing industries of both low and highly knowledge-intensive industries as discussed earlier.

\section{Empirical results}

Table 5 reports two sets of empirical results, namely model (1) that shows the direct effects of knowledge intensity and cultural diversity, and model (2) that extends this to the interaction effects between knowledge intensity and cultural diversity.

To capture the impact of start-ups' embeddedness in knowledge-intensive sectors on various entrepreneurial outcomes, we include a binary variable distinguishing between knowledge-intensive and labour-intensive sectors, following the classification discussed in Section 3. We confirm that new entry and survival rates are higher in the geographically localized industries which exhibit higher embeddedness of technology (Chinitz 1961;
Audretsch 1995; Beaudry and Schiffauerova 2009; Gambardella and Giarratana 2010). Interestingly, while we find the relationship between knowledge-intensive industries and net entry as well as survival to be positive and statistically significant (H1a, H1b), cultural diversity was found positively related to both entrepreneurial outcomes, but being only significant for start-ups' survival (model 1 spec. 1-2, Table 5). An abundance of knowledge is associated with a gradual increase in survival ratio alone with cultural diversity and diverse skills support the rise and growth of diverse markets and diverse ideas (Florida 2002; Putnam 2007). In particular, industries in cities that welcome diverse experiences and preferences (Olfert and Partridge 2011) will feature diversities in newly created market niches which ensure a sustainable demand and supply of a product (H1b). Unlike the high relevance of cultural diversity to firm survival, we do not find support of cultural diversity having a positive impact on net entry. This is because creativity and cultural diversity per se do not create new and challenge incumbent firms (Lee et al. 2004; Audretsch and Belitski 2013;

Table 5 SURE regression results: DV-employment growth, survival and enterprise birth start-up rates

\begin{tabular}{|c|c|c|c|c|c|c|}
\hline \multirow[b]{2}{*}{ Variables } & \multicolumn{3}{|l|}{ Model 1} & \multicolumn{3}{|l|}{ Model 2} \\
\hline & Net entry & Survival & High growth & Net entry & Survival & High growth \\
\hline Specification & 1 & 2 & 3 & 4 & 5 & 6 \\
\hline Population density & $0.20 *(0.11)$ & $-0.038^{*}(0.02)$ & $0.003(0.01)$ & $0.20 *(0.11)$ & $-0.038 *(0.02)$ & $0.003(0.01)$ \\
\hline GDP pc ppp & $-0.27 *(0.16)$ & $\begin{array}{c}-0.063 * * * \\
(0.01)\end{array}$ & $-0.002(0.01)$ & $-0.27 *(0.15)$ & $\begin{array}{c}-0.063 * * * \\
(0.01)\end{array}$ & $-0.002(0.01)$ \\
\hline $\begin{array}{l}\text { Cultural diversity } \\
\text { (H1a, H1b, H1c) }\end{array}$ & $0.13(0.09)$ & $0.016^{* *}(0.01)$ & $0.001(0.00)$ & $0.13(0.09)$ & $0.015 * *(0.01)$ & $0.001(0.00)$ \\
\hline $\begin{array}{l}\text { High-tech/knowledge } \\
\text { intensive } \\
\text { sector } \\
(\mathrm{H} 1 \mathrm{a}, \mathrm{H} 1 \mathrm{~b}, \mathrm{H} 1 \mathrm{c})\end{array}$ & $\begin{array}{c}0.030 * * * \\
(0.01)\end{array}$ & $0.022 * * *(0.00)$ & $\begin{array}{c}-0.002 * * * \\
(0.00)\end{array}$ & $\begin{array}{r}0.030 * * * \\
(0.005)\end{array}$ & $0.022 * * *(0.00)$ & $\begin{array}{c}-0.002 * * * \\
(0.00)\end{array}$ \\
\hline $\begin{array}{l}\text { City culture } \mathrm{x} \\
\text { High-tech }(\mathrm{H} 2 \mathrm{a}, \mathrm{H} 2 \mathrm{~b}, \mathrm{H} 2 \mathrm{c})\end{array}$ & & & & $0.008 * *(0.004)$ & $0.001(.001)$ & $0.001 * *(0.000)$ \\
\hline Constant & $1.08(0.71)$ & $.88^{* * * *}(0.114)$ & $0.001(0.027)$ & $1.07(0.7)$ & $.88 * * *(0.116)$ & $0.001(0.027)$ \\
\hline Time fixed effects & Yes & Yes & Yes & Yes & Yes & Yes \\
\hline Industry fixed effects & Yes & Yes & Yes & Yes & Yes & Yes \\
\hline City fixed effects & Yes & Yes & Yes & Yes & Yes & Yes \\
\hline Rho_12 & \multicolumn{3}{|c|}{$-0.18 * * *(0.05)$} & \multicolumn{3}{|l|}{$-0.19 * * *(0.051)$} \\
\hline Rho_13 & \multicolumn{3}{|l|}{$0.037(0.05)$} & \multicolumn{3}{|l|}{$0.027(0.048)$} \\
\hline Rho_23 & \multicolumn{3}{|c|}{$-0.105 * *(0.05)$} & \multicolumn{3}{|l|}{$-0.105^{* *}(0.05)$} \\
\hline Wald chi2 & \multicolumn{3}{|l|}{8134.42} & \multicolumn{3}{|l|}{8388} \\
\hline No of observations & \multicolumn{3}{|l|}{1144} & \multicolumn{3}{|l|}{1144} \\
\hline
\end{tabular}

$* 0.01, * * 0.05, * * *, 0.01$ significance level. City, industry and countries dummies as well as time period dummies are included to control for unobserved heterogeneity. City and industry dummies are suppressed to safe space. Standard errors are robust for heteroskedasticity. Full regression results for city controls are available on request. Source: Eurostat (2012) 
Dheer 2017), they rather serve as conduit of knowledge spillovers for entrepreneurial outcomes in the context of knowledge-intensive industries. This adds to prior findings that localization of knowledge spillovers benefit skilled workers in knowledge-intensive firms more than unskilled workers in industries with the paucity of knowledge (Gambardella and Giarratana 2010).

As expected, cultural diversity is not directly associated with the rate of high-employment-growth start-ups, whereas we find an adverse relationship between knowledge intensity and high-employment-growth start-ups was confirmed (H1c). Holding other factors constant, in high-knowledge intensive sectors, the ratio of high-growth employment start-ups is on average $0.3 \%$ lower than in low-knowledge intensive sectors. With investment in new technology, labour becomes more productive. However, the price of capital decreases relative to that for labour that may reduce the demand for labour. If the elasticity of technical substitution (capital/labour ratio) is greater than one, the effect of reduction in demand for labour will dominate. To follow, knowledge-intensive firms are likely to hire less but more skilful staff unlike in labour-intensive firms. Knowledge-intensive firms are more likely to outsource operations overseas and develop and apply technologies in collaboration with external partners (Laursen and Salter 2006, 2014; Dahlander and Gann 2010) which decreases labour intensity and is likely to have a negative impact on job creation (Geroski 1995).

Having mentioned the role of cultural diversity as a conduit of knowledge spillover for higher entrepreneurial outcomes, we tested $\mathrm{H} 2 \mathrm{a}-\mathrm{H} 2 \mathrm{c}$ by calculating predictive margins of resource-based low-tech vs. knowledgeintensive high-tech sectors with $90 \%$ confidence intervals on various entrepreneurial outcomes conditional on the degree of cultural diversity in cities. What really matters for new ideas and knowledge to be recognised and introduced to the market is the diversity of people's backgrounds, skills, experiences and competences embedded into a local context (Szerb et al. 2013; Acs et al. 2014; Autio et al. 2014). Therefore, it is cultural diversity at the level of cities where localized knowledge spillovers work (Jaffe et al. 1993; Saxenian 1994; Beaudry and Schiffauerova 2009; Bosma and Sternberg 2014). We find strong support for hypothesis (H2c) with cultural diversity having positive and statistically significant impact as a moderating factor for increasing the rate of high growth start-ups in knowledge-intensive sectors within the range of 0.76 and 2.24 values of the cultural diversity measure out of the estimated sample maximum of 3.6 (see Fig. 1). We explain this by the fact that the overall labour reduction effect is counteracted by an increase in employment of more skilful or talented labour that tends to be more concentrated in culturally diverse contexts.

Cultural diversity is also found to be as important as a conduit of survival for both labour- and knowledgeintensive sectors with its effect being larger for knowledge-intensive sectors supporting H2b (see Fig. 2). Survival of start-ups increases in both types of industries with the increase in cultural diversity in a city, although the effect is more pronounced for knowledgeintensive sectors. More specifically, the increase in the value of cultural diversity from its $10 \%$ lowest centile of the distribution to the $10 \%$ highest, increases the ratio of the survived start-ups in the total proportion of the enterprise population by $6 \%$ in low-tech and $7 \%$ in knowledge-intensive sectors.

The moderation effect of cultural diversity for a new entry is more pronounced in the context of knowledgeintensive start-ups supporting $\mathrm{H} 2 \mathrm{a}$, but only for the limited range of the values of cultural diversity. Interestingly, cultural diversity increases new entry in knowledgeintensive sectors at a higher range of its distribution: the effect kicks in when cultural diversity is at its median level, but with higher values, its statistical significance gradually falls from $1 \%$ to a marginal $10 \%$ level. There is no statistically significant moderating effect of cultural diversity in recourse-based low-tech sectors (see Fig. 3).

In summary, in Table 5, model two supports theoretical insights on the moderating effect of cultural diversity to be idiosyncratic for different entrepreneurial outcomes and across the knowledge intensity of an industry. The results have remained robust when we dropped the 'industry' category, which includes low-, medium- and high-tech manufacturing and machinery, from the analysis to retain only sectors with the straightforward classification as hightech knowledge-intensive sectors (Table 6).

\section{Conclusion}

A number of studies draw on the cultural diversity, and knowledge constructs aim to depict and explain different aspects of the entrepreneurship dynamics and market processes (Qian 2013; Audretsch et al. 2015a; Dheer 2017; Spanjer and van Witteloostuijn 2017), and there is still lack of a systemic analysis linking knowledge and 


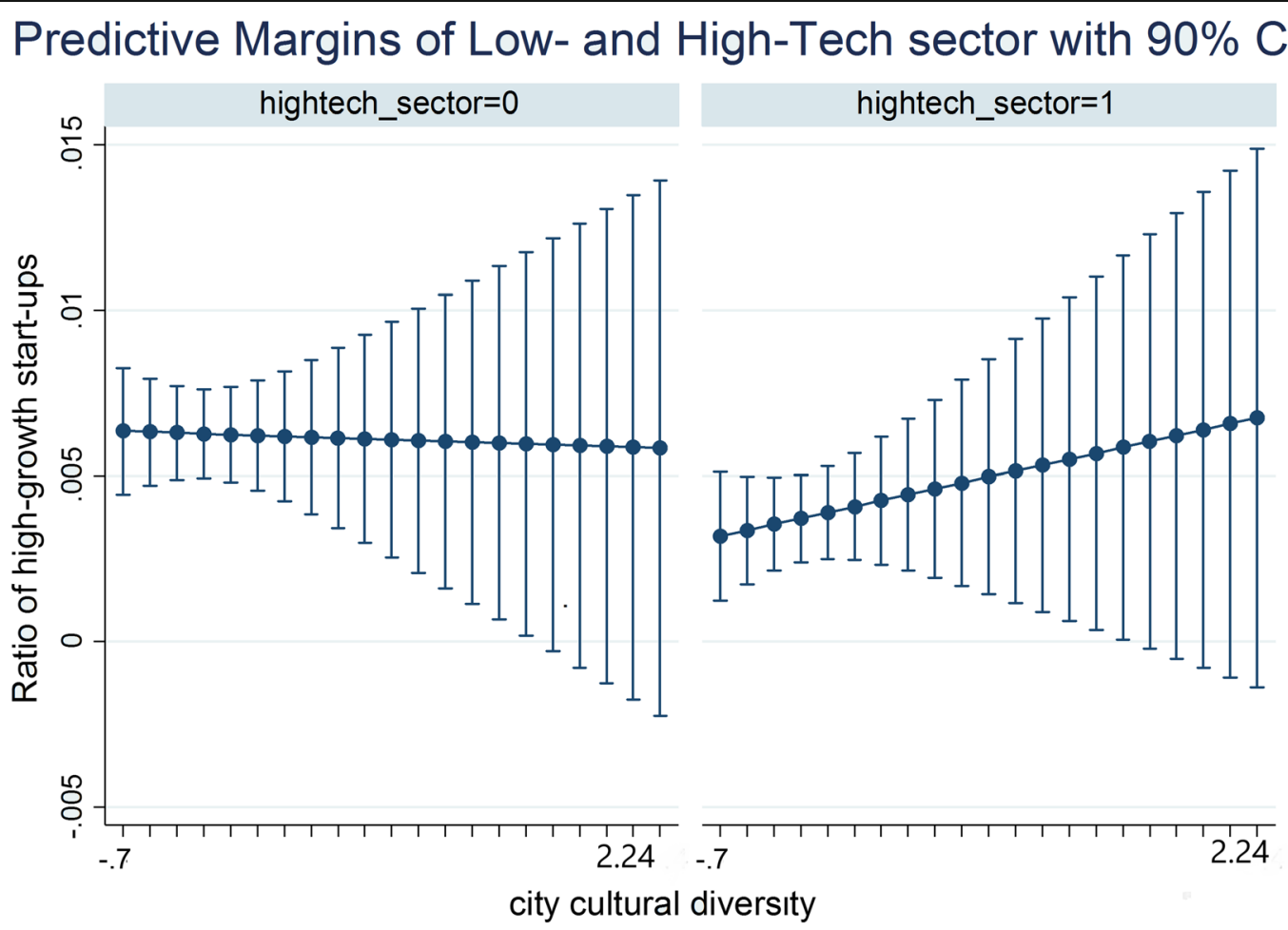

Fig. 1 Predictive margins of cultural diversity as a moderator of high growth start-up ratio in low- and high-tech sectors with $90 \%$ CIs. Source: authors' calculations based on Eurostat (2012)

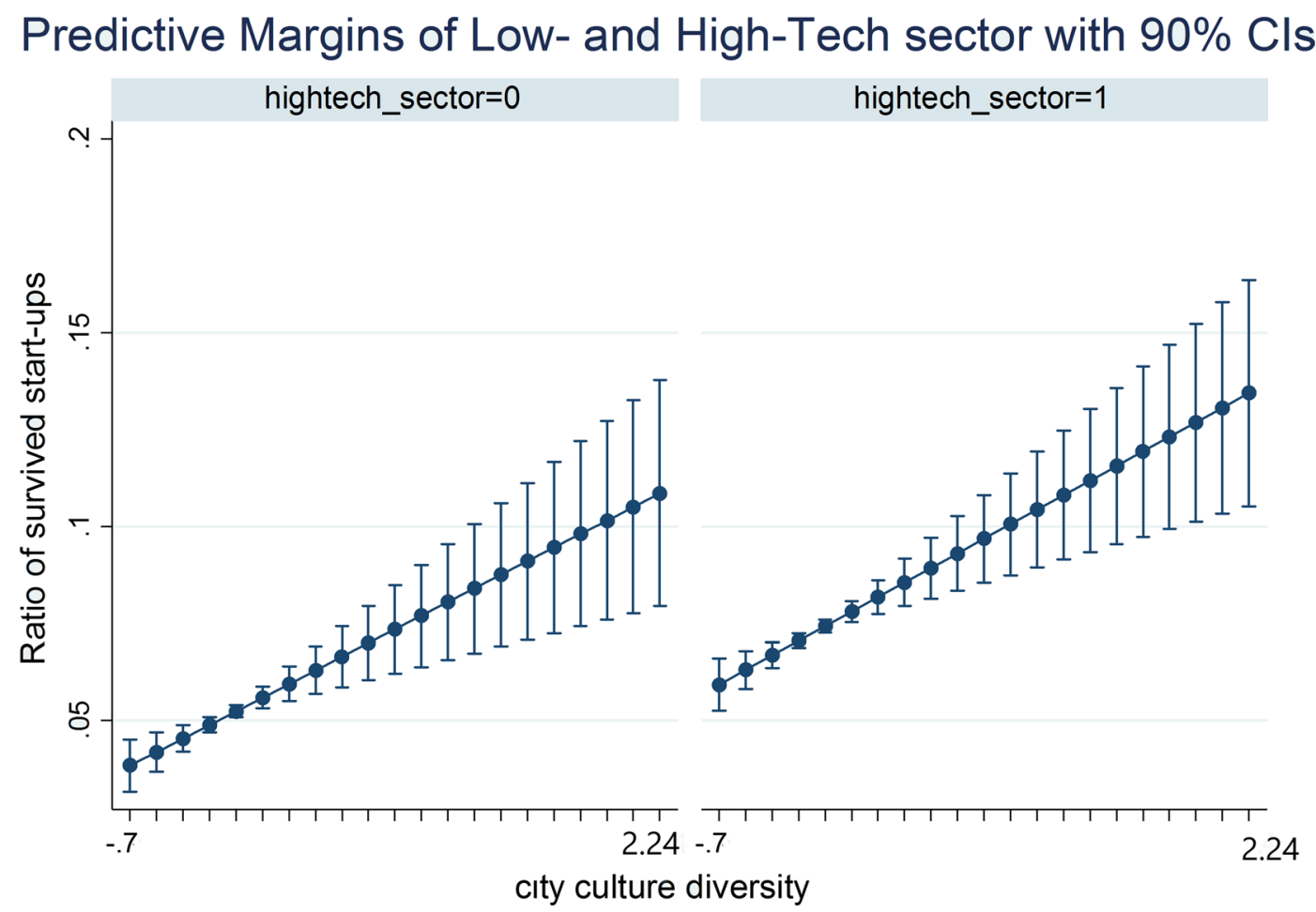

Fig. 2 Predictive margins of cultural diversity as a moderator of survival ratio in low- and high-tech sectors with $90 \%$ CIs. Source: authors' calculations based on Eurostat (2012) 
Predictive Margins of Low- and High-Tech sector with $90 \%$ Cls

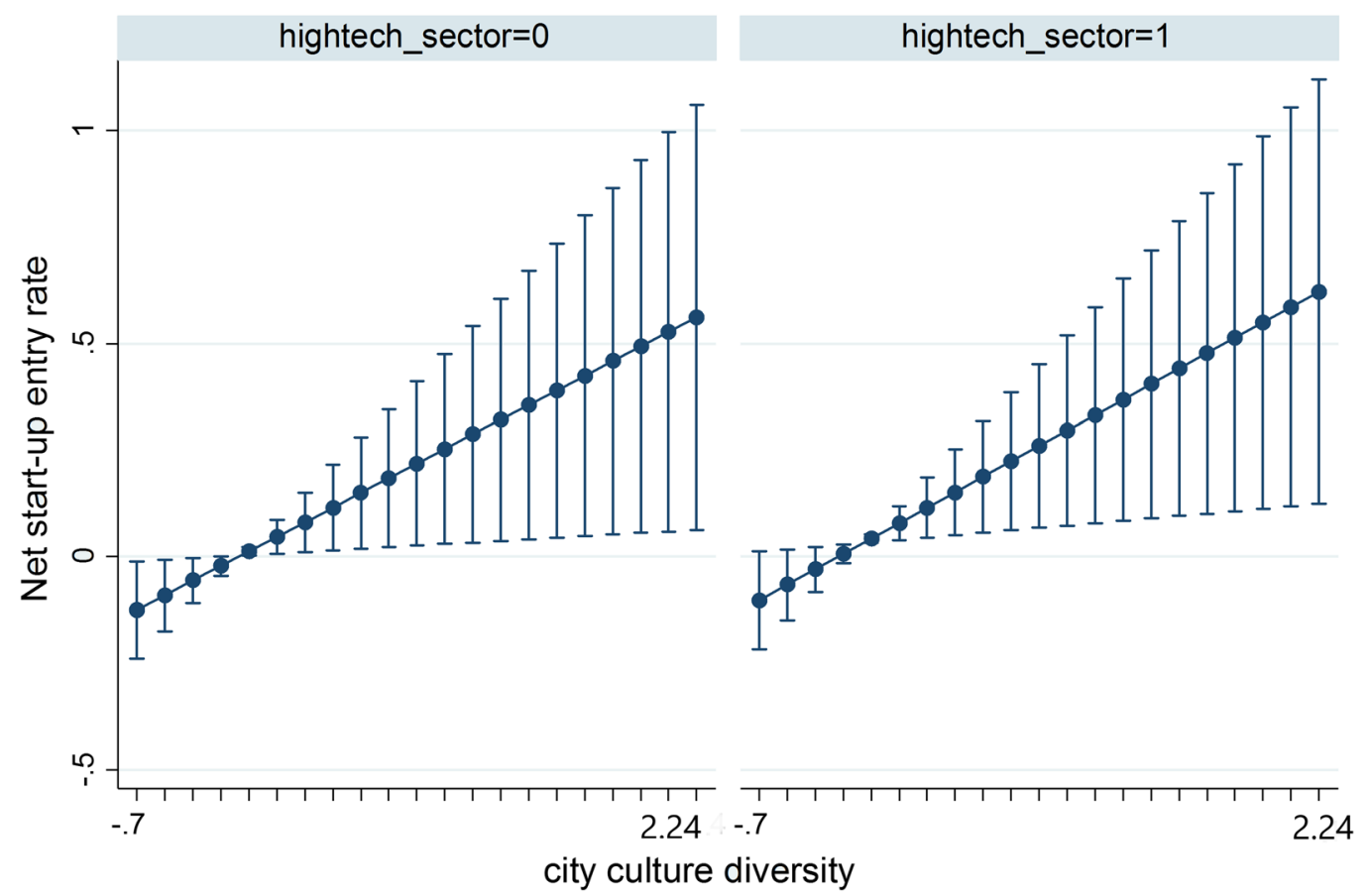

Fig. 3 Predictive margins of cultural diversity as a moderator of net entry in low- and high-tech sectors with 90\% CIs. Source: authors' calculations based on Eurostat (2012)

diversity to entrepreneurial outcomes especially in the context of cross-city cross-country comparisons. In particular, cultural diversity and knowledge are important antecedents of productivity, innovation, market response across teams, firms and countries (Gomez-Mejia and Palich 1997; Szerb et al. 2013) which foster recognition and transformation of new knowledge into marketable products (Qian 2013; Nathan 2012). This study offers interesting findings concerning the role of cultural diversity in the strategic management of the knowledge spillover entrepreneurship across cities in the international setting.

First, we contend that along with knowledge intensity embedded in industries, cultural diversity facilitates agile decision-makers and combines ideas to arrive at a new knowledge (Sobel et al. 2010; Qian and Acs 2013).

Second, industries rich in knowledge benefit more from local diversity than in industries with paucity of knowledge (Audretsch et al. 2010; Gambardella and Giarratana 2010). The knowledge spillovers are interdependent, and the realization of entrepreneurial opportunities leading to the development of competitive advantage depends on strategic alignment of tacit knowledge and cultural diversity of cities (Sobel et al. 2010; Nathan 2012; Qian and Acs 2013).
This study makes the following important contributions in strategic international entrepreneurship and regional development literatures.

First, it makes a methodological and empirical contribution to strategic international entrepreneurship and international business literature by merging the multisource data and providing a multi-level (industry-citycountry) perspective to study the complexity of the relationship between entrepreneurial outcomes, knowledge, embedded in industries and cultural diversity across-city and across-country, as well as provide more comparative evidence across European countries and time. We construct a new measure of cultural diversity, which reflects both the importance of cultural amenities and localized knowledge exchange between people and firms (Van Wijk et al. 2008) as a source of creativity and diversity (Florida 2002).

Second, this study addresses the call in the emerging field of strategic international entrepreneurship literature on how cities can exploit knowledge spillovers to create new firms and generate competitive advantage through cultural diversity in different international settings (Tung 2008; Gambardella and Giarratana 2010; Agarwal et al. 2010; Marino et al. 2012). We confront this question by 
Table 6 Robustness checks: SURE regression results: DV-employment growth, survival and enterprise birth rate (start-ups) with the 'industry' category excluded from the estimations

\begin{tabular}{|c|c|c|c|c|c|c|}
\hline \multirow[b]{2}{*}{ Variables } & \multicolumn{3}{|l|}{ Model 1} & \multicolumn{3}{|l|}{ Model 2} \\
\hline & Net entry & Survival & High-growth & Net entry & Survival & High-growth \\
\hline Specification & 1 & 2 & 3 & 4 & 5 & 6 \\
\hline Population density & $0.26 * *(0.11)$ & $-0.037(0.02)$ & $0.004(0.01)$ & $0.26 * *(0.11)$ & $-0.037(0.02)$ & $0.003(0.01)$ \\
\hline GDP pc ppp & $\begin{array}{r}-0.35 * * \\
(0.16)\end{array}$ & $\begin{array}{c}-0.068 * * * \\
(0.01)\end{array}$ & $-0.001(0.01)$ & $\begin{array}{c}-0.35 * * \\
(0.16)\end{array}$ & $\begin{array}{c}-0.068 * * * \\
(0.01)\end{array}$ & $-0.001(0.01)$ \\
\hline Cultural diversity (H1a, H1b, H1c) & $0.17 * *(0.09)$ & $0.018 * *(0.01)$ & $0.0004(0.001)$ & $0.17 *(0.09)$ & $0.018 * *(0.01)$ & $-0.000(0.001)$ \\
\hline $\begin{array}{l}\text { High-tech/knowledge-intensive } \\
\text { sector } \\
(\mathrm{H} 1 \mathrm{a}, \mathrm{H} 1 \mathrm{~b}, \mathrm{H} 1 \mathrm{c})\end{array}$ & $\begin{array}{c}0.029 * * * \\
(0.01)\end{array}$ & $\begin{array}{r}0.022 * * * \\
(0.002)\end{array}$ & $\begin{array}{c}-0.002 * * * \\
(0.001)\end{array}$ & $\begin{array}{c}0.029 * * * \\
(0.01)\end{array}$ & $\begin{array}{r}0.022 * * * \\
(0.002)\end{array}$ & $\begin{array}{c}-0.002 * * * \\
(0.001)\end{array}$ \\
\hline $\begin{array}{l}\text { Cultural diversity } x \\
\text { High-tech }(\mathrm{H} 2 \mathrm{a}, \mathrm{H} 2 \mathrm{~b}, \mathrm{H} 2 \mathrm{c})\end{array}$ & & & & $\begin{array}{l}0.009 * * \\
(0.004)\end{array}$ & $0.001(0.001)$ & $\begin{array}{r}-0.001 * * \\
(0.0003)\end{array}$ \\
\hline Constant & $1.39 *(0.75)$ & $\begin{array}{r}.916^{* * * *} \\
(0.123)\end{array}$ & $-0.007(0.028)$ & $1.39 *(0.75)$ & $\begin{array}{r}0.916 * * * \\
(0.123)\end{array}$ & $-0.007(0.028)$ \\
\hline Time fixed effects & Yes & Yes & Yes & Yes & Yes & Yes \\
\hline Industry fixed effects & Yes & Yes & Yes & Yes & Yes & Yes \\
\hline City fixed effects & Yes & Yes & Yes & Yes & Yes & Yes \\
\hline Rho_12 & \multicolumn{3}{|c|}{$-0.19 * * *(0.05)$} & \multicolumn{3}{|c|}{$-0.209 * * *(0.05)$} \\
\hline Rho_13 & \multicolumn{3}{|l|}{$0.047(0.05)$} & \multicolumn{3}{|l|}{$0.035(0.05)$} \\
\hline Rho_23 & \multicolumn{3}{|l|}{$-0.105^{*}(0.05)$} & \multicolumn{3}{|c|}{$-0.103 *(0.05)$} \\
\hline Wald chi2 & \multicolumn{3}{|l|}{6869} & \multicolumn{3}{|l|}{7130} \\
\hline No of observations & \multicolumn{3}{|l|}{1040} & \multicolumn{3}{|l|}{1040} \\
\hline
\end{tabular}

*0.01, **0.05,***0.01 significance level. 'Industry' category includes manufacturing; mining and quarrying; electricity and gas; and water supply which are related to low-, medium- and high-tech manufacturing sector. City, industry and countries dummies as well as time period dummies are included to control for unobserved heterogeneity. City and industry dummies are suppressed to safe space. Standard errors are robust for heteroskedasticity. Full regression results for city controls are available on request. Source: Eurostat (2012)

following the 'creative construction' approach (Agarwal et al. 2007) and Knowledge Spillover Entrepreneurship prospective (Audretsch and Lehmann 2005) to establish and test the relationship between knowledge intensity and cultural diversity empirically, finding that their direct effect and the interplay between them might be particularly valuable for only certain entrepreneurial outcomes.

Our theoretical insights have been validated empirically using the sophisticated seemingly unrelated regression equations model to simultaneously study all three entrepreneurial outcomes of interest, accounting therefore for potential endogeneity between them.

To conclude, the results in this study illustrate that higher cultural diversity in cities is likely to increase enterprise survival and sustainability through exploring new knowledge and introducing it to the market (Nathan 2012; Audretsch and Belitski 2013). Higher survival ratio may create pre-conditions for insourcing rather than outsourcing jobs, in particular, in knowledgeintensive sectors with positive implications for high growth. Alone with knowledge embedded into industry (Battke et al. 2016), cultural diversity is embodied into people and cities (Florida 2002; Lee et al. 2004; Glaeser 2005) creating more efficient local entrepreneurial ecosystem conducive to start-ups' entry, survival and growth (Szerb et al. 2013; Acs et al. 2013, 2014).

Subsequent studies should focus on building out the framework introduced in this paper by analysing how the combination of cultural diversity and knowledge intensity could be used to enhance entrepreneurial orientation and generate competitive advantage in firms. The model could be extended to pre-empt a change in strategy and implement a new combination of knowledge and cultural diversity by re-allocating the entrepreneurial ecosystem resources. Combined strategic planning through industry-city and country levels is vital to the efficient alignment of cultural diversity and knowledge and could become a distinctive subject of future research. 
Appendix: Average value of DVs (2008-2010) by city included in this study

\begin{tabular}{|c|c|c|c|c|c|c|c|c|c|}
\hline City & $\begin{array}{l}\text { No. of } \\
\text { sectors }\end{array}$ & $\begin{array}{l}\text { High } \\
\text { growth }\end{array}$ & Survival & Net entry & City & $\begin{array}{l}\text { No. of } \\
\text { sectors }\end{array}$ & $\begin{array}{l}\text { High } \\
\text { growth }\end{array}$ & Survival & Net entry \\
\hline Alba Iulia & 11 & 0.006 & 0.101 & 0.051 & Lublin & 22 & & 0.067 & 0.057 \\
\hline Alicante/Alacant & 11 & 0.005 & 0.068 & -0.016 & Madrid & 11 & 0.008 & 0.057 & 0.001 \\
\hline Aquila & 22 & 0.003 & 0.057 & -0.112 & Malaga & 11 & 0.004 & 0.066 & -0.010 \\
\hline Bacau & 11 & 0.006 & 0.100 & 0.050 & Milano & 22 & 0.005 & 0.048 & 0.010 \\
\hline Badajoz & 11 & 0.004 & 0.056 & 0.001 & Murcia & 11 & 0.006 & 0.068 & -0.015 \\
\hline Barcelona & 11 & 0.006 & 0.067 & -0.003 & Napoli & 22 & 0.005 & 0.064 & 0.008 \\
\hline Bari & 22 & 0.005 & 0.059 & 0.010 & Olomouc & 11 & & 0.050 & \\
\hline Bialystok & 22 & & 0.067 & 0.052 & Opole & 22 & & 0.065 & 0.043 \\
\hline Bologna & 22 & 0.004 & 0.046 & 0.003 & Padova & 22 & 0.004 & 0.046 & 0.006 \\
\hline Braila & 11 & 0.009 & 0.106 & 0.043 & Palermo & 22 & 0.004 & 0.055 & 0.005 \\
\hline Brescia & 22 & 0.004 & 0.050 & 0.009 & Perugia & 22 & 0.004 & 0.050 & 0.000 \\
\hline Bucuresti & 11 & 0.008 & 0.105 & 0.051 & Pescara & 22 & 0.003 & 0.059 & 0.006 \\
\hline Budapest & 22 & 0.007 & 0.047 & 0.000 & Plzen & 11 & & 0.045 & \\
\hline Cagliari & 22 & 0.005 & 0.058 & 0.003 & Poznan & 22 & & 0.068 & 0.046 \\
\hline Campobasso & 22 & 0.003 & 0.058 & 0.016 & Presov & 11 & 0.005 & 0.070 & 0.054 \\
\hline Caserta & 22 & 0.004 & 0.068 & 0.010 & Roma & 22 & 0.004 & 0.058 & 0.018 \\
\hline Catania & 22 & 0.003 & 0.067 & 0.012 & Sassari & 22 & 0.002 & 0.054 & 0.009 \\
\hline Cordoba & 11 & 0.005 & 0.060 & 0.001 & Sevilla & 11 & 0.007 & 0.062 & 0.004 \\
\hline Coruna & 11 & 0.008 & 0.057 & 0.010 & Sibiu & 11 & 0.007 & 0.098 & 0.036 \\
\hline Firenze & 22 & 0.004 & 0.051 & 0.002 & Suwalki & 22 & & 0.063 & 0.057 \\
\hline Foggia & 22 & 0.002 & 0.060 & 0.013 & Szczecin & 22 & & 0.066 & 0.036 \\
\hline Gdansk & 22 & & 0.065 & 0.063 & Taranto & 22 & 0.005 & 0.061 & 0.011 \\
\hline Genova & 22 & 0.004 & 0.052 & 0.003 & Toledo & 11 & 0.004 & 0.059 & -0.010 \\
\hline Graz & 11 & 0.010 & 0.051 & 0.003 & Torino & 22 & 0.004 & 0.051 & 0.011 \\
\hline Gyor & 22 & 0.005 & 0.049 & 0.002 & Trencin & 11 & 0.006 & 0.067 & 0.031 \\
\hline Innsbruck & 11 & 0.008 & 0.052 & 0.011 & Trento & 22 & 0.004 & 0.044 & 0.004 \\
\hline Karlovy Vary & 11 & & 0.049 & & Usti nad Labem & 11 & & 0.053 & \\
\hline Katowice & 22 & & 0.064 & 0.035 & Valencia & 11 & 0.005 & 0.061 & -0.011 \\
\hline Kobenhavn & 11 & 0.007 & 0.076 & 0.024 & Valladolid & 11 & 0.005 & 0.062 & -0.001 \\
\hline Kosice & 11 & 0.007 & 0.062 & 0.028 & Verona & 22 & 0.004 & 0.049 & 0.004 \\
\hline Krakow & 22 & & 0.067 & 0.049 & Warszawa & 22 & & 0.071 & 0.046 \\
\hline Liberec & 11 & & 0.050 & & Wroclaw & 22 & & 0.070 & 0.050 \\
\hline \multirow[t]{2}{*}{ Lodz } & 22 & & 0.066 & 0.038 & Zilina & 11 & 0.007 & 0.078 & 0.029 \\
\hline & & & & & Zlin & 11 & & 0.048 & \\
\hline
\end{tabular}

1144 observations, 11 industries, two time periods, 8 countries and 67 cities. Sorted alphabetically by city name. Source: Eurostat (2012)

Open Access This article is distributed under the terms of the Creative Commons Attribution 4.0 International License (http:// creativecommons.org/licenses/by/4.0/), which permits unrestricted use, distribution, and reproduction in any medium, provided you give appropriate credit to the original author(s) and the source, provide a link to the Creative Commons license, and indicate if changes were made.

\section{References}

Acs, Z. J., Audretsch, D. B., \& Lehmann, E. E. (2013). The knowledge spillover theory of entrepreneurship. Small Business Economics, 41(4), 757-774.

Acs, Z. J., Autio, E., \& Szerb, L. (2014). National Systems of entrepreneurship: measurement issues and policy implications. Research Policy, 43, 476-449. 
Agarwal, R., \& Audretsch, D. B. (2001). Does entry size matter? The impact of the life cycle and technology on firm survival. The Journal of Industrial Economics, 49(1), 21-43.

Agarwal, R., Audretsch, D. B., \& Sarkar, M. B. (2007). The process of creative construction: knowledge spillovers, entrepreneurship, and economic growth. Strategic Entrepreneurship Journal, 1(3-4), 263-286.

Agarwal, R., Audretsch, D. B., \& Sarkar, M. B. (2010). Knowledge spillovers and strategic entrepreneurship. Strategic Entrepreneurship Journal, 4(4), 271-283.

Ahlstrom, D., \& Bruton, G. D. (2002). An institutional perspective on the role of culture in shaping strategic actions by technology-focused entrepreneurial firms in China. Entrepreneurship Theory and Practice, 26(4), 53-70.

Audretsch, D. B. (1995). Innovation, growth and survival. International Journal of Industrial Organization, 13(4), 441-457.

Audretsch, D. B., \& Feldman, M. P. (1996). R\&D spillovers and the geography of innovation and production. The American Economic Review, 630-640.

Audretsch, D. B., \& Lehmann, E. E. (2005). Does the knowledge spillover theory of entrepreneurship hold for regions? Research Policy, 34(8), 1191-1202.

Audretsch, D. B., Keilbach, M., \& Lehmann, E. (2006). Entrepreneurship and economic growth. New York: Oxford University Press.

Audretsch, D. B. (2007). The entrepreneurial society. New York: Oxford University Press.

Audretsch, D. B., \& Dohse, D. (2007). Location: a neglected determinant of firm growth. Review of World Economics, 143(1), 79-107.

Audretsch, D. B., Dohse, D., \& Niebuhr, A. (2010). Cultural diversity and entrepreneurship: a regional analysis for Germany. The Annals of Regional Science, 45(1), 55-85.

Audretsch, D. B., \& Belitski, M. (2013). The missing pillar: the creativity theory of knowledge spillover entrepreneurship. Small Business Economics, 41(4), 819-836.

Audretsch, D. B., Belitski, M., \& Desai, S. (2015a). Entrepreneurship and economic development in cities. The Annals of Regional Science, 55(1), 33-60.

Audretsch, D. B., Heger, D., \& Veith, T. (2015b). Infrastructure and entrepreneurship. Small Business Economics, 44(2), 219-230.

Audretsch, D. B., \& Belitski, M. (2016). Entrepreneurial ecosystems in cities: establishing the framework conditions. Journal of Technology Transfer, 1-22.

Autio, E., Kenney, M., Mustar, P., Siegel, D. S., \& Wright, M. (2014). Entrepreneurial innovation: the importance of context. Research Policy, 43(7), 1097-1108.

Autio, E., Pathak, S., \& Wennberg, K. (2013). Consequences of cultural practices for entrepreneurial behaviors. Journal of International Business Studies, 44(4), 334-362.

Battke, B., Schmidt, T. S., Stollenwerk, S., \& Hoffmann, V. H. (2016). Internal or external spillovers - which kind of knowledge is more likely to flow within or across technologies. Research Policy, 45(1), 27-41.

Beaudry, C., \& Schiffauerova, A. (2009). Who's right, Marshall or Jacobs? The localization versus urbanization debate. Research Policy, 38(2), 318-337.
Boschma, R. A., \& Fritsch, M. (2009). Creative class and regional growth: empirical evidence from seven European countries. Economic Geography, 85(4), 391-423.

Bosma, N. S., Hessels, J., Schutjens, V., Praag, M., \& Verheul, I. (2012). Entrepreneurship and role models. Journal of Economic Psychology, 33(2), 410-424.

Bosma, N. S., \& Sternberg, R. (2014). Entrepreneurship as an urban event? Empirical evidence from European cities. Regional Studies, 48, 1016-1033.

Brülhart, M., \& Träger, R. (2005). An account of geographic concentration patterns in Europe. Regional Science and Urban Economics, 35, 597-624.

Chambers, D., \& Hamer, S. (2012). Culture and growth: some empirical evidence. Bulletin of Economic Research, 64(4), 549-564.

Chinitz, B. (1961). Contrasts in agglomeration: New York and Pittsburgh. The American Economic Review, 279-289.

Coad, A., Frankish, J., Roberts, R. G., \& Storey, D. J. (2013). Growth paths and survival chances: an application of Gambler's ruin theory. Journal of Business Venturing, 28(5), 615-632.

Dahlander, L., \& Gann, D. M. (2010). How open is innovation? Research Policy, 39(6), 699-709.

Cowen, T., 2002. Creative destruction: how globalization is changing the world's culture. Princeton University Press, Princeton.

Delgado, M., Porter, M. E., \& Styern, S. (2010). Clusters and entrepreneurship. Journal of Economic Geography, 10(4), 495-518.

Delmar, F., Wennberg, K., \& Hellerstedt, K. (2011). Endogenous growth through knowledge spillovers in entrepreneurship: an empirical test. Strategic Entrepreneurship Journal, 5(3), 199-226.

Dheer, R. J. (2017). Cross-national differences in entrepreneurial activity: role of culture and institutional factors. Small Business Economics, 48, 813-842.

Eurostat, 2012. City statistics urban audit; URL http://epp.eurostat. ec.europa.eu/portal/page/portal/region_cities/city_urban (accessed 7.04.15).

Eurostat, 2015. What is a city? - spatial units; URL http://ec. europa.eu/eurostat/web/cities/spatial-units. (accessed 7.03.15).

Eurostat, 2014. High-tech industry and knowledge-intensive services; available from http://ec.europa. eu/eurostat/cache/metadata/Annexes/htec_esms_an3.pdf [accessed 09.09.16].

Falck, O., Fritsch, M., \& Heblich, S. (2011). The phantom of the opera: Cultural amenities, human capital, and regional economic growth. Labor Economics, 18(6), 755-766.

Florida, R. L. (2002). The rise of the creative class. New York: Basic Books.

Florida, R. L., Mellander, C., \& Stolarick, K. (2008). Inside the black box of regional development - human capital, the creative class and tolerance. Journal of Economic Geography, 8(5), 615-649.

Fujita, M., \& Weber, S. (2003). Strategic immigration policies and welfare in heterogeneous countries, CORE Discussion Papers 2003095, Université catholique de Louvain, Center for Operations Research and Econometrics (CORE). 
Gambardella, A., \& Giarratana, M. S. (2010). Localized knowledge spillovers and skill-biased performance. Strategic Entrepreneurship Journal, 4(4), 323-339.

Geroski, P. A. (1995). What do we know about entry? International Journal of Industrial Organization, 13, 421440.

Glaeser, E. L., Kolko, J., \& Saiz, A. (2001). Consumer city. Journal of Economic Geography, 1(1), 27-50.

Glaeser, E.L., Saiz, A., Burtless, G., Strange, W. C. 2004. The rise of the skilled city. Brookings-Wharton Papers on Urban Affairs, 47-105.

Glaeser, E. L. (2005). Reinventing Boston: 1630-2003. Journal of Economic Geography, 5(2), 119-153.

Glaeser, E. L., Rosenthal, S. S., \& Strange, W. C. (2010). Urban economics and entrepreneurship. Journal of Urban Economics, 67, 1-14.

Glaeser, E. L., Ponzetto, G. A., \& Tobio, K. (2014). Cities, skills and regional change. Regional Studies, 48(1), 7-43.

Gomez-Mejia, L. R., \& Palich, L. E. (1997). Cultural diversity and the performance of multinational firms. Journal of International Business Studies, 309-335.

Hitt, M. A., Sexton, D. L., Ireland, R. D. and Camp, S. M., 2002. Strategic entrepreneurship: Integrating entrepreneurial and strategic management perspectives. Strategic entrepreneurship: creating a new mindset. Blackwell Publishers, Oxford., 1-16.

Jaffe, A., Trajtenberg, M., \& Henderson, R. (1993). Geographic localization of knowledge spillovers as evidenced by patent citations. Quarterly Journal of Economics, 63, 577-598.

Kenney, M., Breznitz, D., \& Murphree, M. (2013). Coming back home after the sun rises: returnee entrepreneurs and growth of high tech industries. Research Policy, 42(2), 391-407.

Korosteleva, J., \& Belitski, M. (2017). Entrepreneurial dynamics and higher education institutions in the post-communist world. Regional Studies, 51(3), 439-453.

Kreiser, P. M., Marino, L. D., Dickson, P., and Weaver, K. M. 2010. Cultural influences on entrepreneurial orientation: the impact of national culture on risk taking and proactiveness in SMEs. Entrepreneurship Theory and Practice 34(5), 959983.

Landry, C., \& Wood, P. (2008). The Intercultural City: Planning for diversity advantage. London: Earthscan.

Laursen, K., Salter, A., 2006. Open for innovation: the role of openness in explaining innovation performance among UK manufacturing firms. Strategic Management Journal 27(2), 131-150.

Laursen, K., Salter, A. J., 2014. The paradox of openness: appropriability, external search and collaboration. Research Policy 43(5), 867-878.

Lee, S.Y., Florida, R., Acs, Z., 2004. Creativity and entrepreneurship: a regional analysis of new firm formation. Regional Studies 38(8), 879-891.

Lee, N. (2011). Ethnic diversity and employment growth in English cities. Urban Studies, 48, 407-425.

LEAD, 2014. e-Leadership Skills for Competitiveness and Innovation. European Commission; URL http://ec.europa. eu/enterprise/sectors/ict/files/eskills/insead_eleadership_en. pdf. (accessed 15.03.15).

Leung, K., Bhagat, R. S., Buchan, N. R., Erez, M., \& Gibson, C. B. (2005). Culture and international business: recent advances and their implications for future research. Journal of International Business Studies, 357-378.

Li, W., Liu, K., Belitski, M., Ghobadian, A., \& O'Regan, N. (2016). e-Leadership through strategic alignment: an empirical study of small and medium sized enterprises in the digital age. Journal of Information Systems.

Liu, X., Lu, J., Filatotchev, I., Buck, T., \& Wright, M. (2010). Returnee entrepreneurs, knowledge spillovers and innovation in high-tech firms in emerging economies. Journal of International Business Studies, 41(7), 1183-1197.

Legrain, P., 2006. Immigrants: Your Country Needs Them. Little, Brown, London.

Leyden, D., Link, A., \& Siegel, D. S. (2014). A theoretical analysis of the role of social networks in entrepreneurship. Research Policy, 43(7), 1157-1163.

Marino, M., Parrotta, P., \& Pozzoli, D. (2012). Does labor diversity promote entrepreneurship? Economics Letters, 116(1), 15-19.

Martin, L. M., \& Wright, L. T. (2005). No gender in cyberspace? Empowering entrepreneurship and innovation in female-run ICT small firms. International Journal of Entrepreneurial Behaviour Research, 11(2), 162-178.

Nathan, M. (2012). After Florida: towards an economics of diversity. European Urban and Regional Studies.

OECD, 2011. ISIC REV. 3 Technology intensity definition. Classification of industries into categories based on $R \& D$ intensities; URL http://www.oecd.org/sti/ind/48350231.pdf. (accessed 27.05.15).

Olfert, M. R., Partridge, M., 2011. Creating the cultural community: ethnic diversity vs. agglomeration. Spatial Economic Analysis 6(1), 25-55.

Page, S., 2007. The difference: how the power of diversity creates better groups, firms, schools and societies. Princeton University Press, Princeton.

Putnam, R., 2007. E Pluribus Unum: diversity and community in the twenty-first century. Scandinavian Political Studies 30, 137-174.

Rauch, A., Frese, M., Wang, Z.-M., Unger, J., Lozada, M., Kupcha, V., et al. (2013). National culture and cultural orientations of owners affecting the innovation-growth relationship in five countries. Entrepreneurship \& Regional Development, 25(9-10), 732-755.

Qian, H. (2013). Diversity versus tolerance: the social drivers of innovation and entrepreneurship in US cities. Urban Studies, 50(13), 2718-2735.

Qian, H., \& Acs, Z. J. (2013). An absorptive capacity theory of knowledge spillover entrepreneurship. Small Business Economics, 40(2), 185-197.

Robertson, M., \& Swan, J. (2003). Control-what control? Culture and ambiguity within a knowledge intensive firm. Journal of Management Studies, 40(4), 831-858.

Roodman, D., 2009. Estimating fully observed recursive mixedprocess models with cmp, CGD. SSRN Working Paper 1392466.

Saridakis, G., Mole, K., \& Storey, D. J. (2008). New small firm survival in England. Empirica, 35(1), 25-39.

Saxenian, A.L., 1994. Regional advantage: culture and competition in Silicon Valley and Route 128. Harvard University Press, Cambridge. 
Shane, S., \& Venkataraman, S. (2000). The promise of entrepreneurship as a field of research. Academy of Management Review, 25(1), 217-226.

Shapiro, J.M., 2003. Smart cities: explaining the relationship between city growth and human capital. SSRN Working paper 480172 .

Siegel, D. S., \& Renko, M. (2012). The roles of market and technological knowledge in recognizing entrepreneurial opportunities. Management Decision, 50(5), 797-816.

Sobel, R. S., Dutta, N., \& Roy, S. (2010). Does cultural diversity increase the rate of entrepreneurship? The Review of Austrian Economics, 23(3), 269-286.

Spanjer, A., \& van Witteloostuijn, A. (2017). The entrepreneur's experiential diversity and entrepreneurial performance. Small Business Economics, 49(1), 141-161.

Stearns, T. M., Carter, N. M., Reynolds, P. D., \& Williams, M. L. (1995). New firm survival: industry, strategy, and location. Journal of Business Venturing, 10(1), 23-42.

Szerb, L., Acs, Z., Autio, E., Ortega-Argiles, R., Komlosi, E. et. al., 2013. REDI: The Regional Entrepreneurship and Development Index - measuring regional entrepreneurship. Final Report. Terjesen, S.,

Stahl, G. K., Maznevski, M. L., Voigt, A., \& Jonsen, K. (2010). Unraveling the effects of cultural diversity in teams: a metaanalysis of research on multicultural work groups. Journal of International Business Studies, 41(4), 690-709.
Teece, D. J., Pisano, G., \& Shuen, A. (1997). Dynamic capabilities and strategic management. Strategic Management Journal, $18,509-533$.

Tidd, J. and Bessant, J. (2014). Strategic innovation management. John Wiley \& Sons.

Tung, R. L. 2008. The cross-cultural research imperative: the need to balance cross-national and intra-national diversity. Journal of International Business Studies, 39(1), 41-46.

Van Wijk, R., Jansen, J. J., \& Lyles, M. A. (2008). Inter-and intraorganizational knowledge transfer: a meta-analytic review and assessment of its antecedents and consequences. Journal of Management Studies, 45(4), 830-853.

Zahra, S.A., Wright, M., 2011. Entrepreneurship's next act. The Academy of Management Perspectives 25(4), 67-83.

Zellner, A. (1962). An efficient method of estimating seemingly unrelated regression equations and tests for aggregation bias. Journal of the American Statistical Association, 57, 348368 .

Publisher's note Springer Nature remains neutral with regard to jurisdictional claims in published maps and institutional affiliations. 